\title{
Determination of Biochemical Profile of Bilecik Propolis
}

\section{Bilecik Propolisinin Biyokimyasal Profilinin Belirlenmesi}

\author{
Merve Keskin ${ }^{1^{*}}$, Şaban Keskin ${ }^{1}$, Nazlı Mayda2 ${ }^{\circledR}$, Aslı Özkök ${ }^{3}$ \\ ${ }^{1}$ Vocational School of Health Services, Bilecik Şeyh Edebali University, Bilecik, Turkey. \\ ${ }^{2}$ Department of Biology, Hacettepe University, Ankara, Turkey. \\ ${ }^{3}$ Hacettepe University, Bee and Bee Products Research and Application Center (HARUM), Ankara, Turkey.
}

\section{ABSTRACT}

ropolis, an important bee product, is used as a food supplement in apitherapy applications and daily life due to its antioxidant antimicrobial, antitumoral and anti-inflammatory properties. The properties of propolis vary depending on the region in which it is obtained, the time and the form of collection. It is not possible to obtain propolis with the same characteristics from each hive or region. In this study, raw propolis samples were obtained from Bilecik province in Marmara Region and their biochemical properties were determined. Bilecik is rich in forestry covered with oak, beech, fir, linden and chestnut trees. Therefore, it has a rich flora. In order to determine the properties of propolis samples, ethanol extract of each sample was prepared separately by using $70 \%$ ethanol. The amount of balsam, wax, total phenolics and total flavonoid of each sample was determined. Chemical composition of each propolis sample was determined by using GC-MS. The amount of balsam which is an important quality parameter for propolis was found to vary between $13 \%$ and $52 \%$. It was also found that total phenolic content ranged from 11 $\mathrm{mg} \mathrm{GAE} \mathrm{/} \mathrm{mL} \mathrm{to} 76 \mathrm{mg} \mathrm{GAE} \mathrm{/} \mathrm{mL.} \mathrm{It} \mathrm{is} \mathrm{determined} \mathrm{that} \mathrm{propolis} \mathrm{samples} \mathrm{were} \mathrm{rich} \mathrm{in} \mathrm{aldehydes,} \mathrm{aliphatic} \mathrm{acid} \mathrm{and} \mathrm{esters,} \mathrm{alcohols,}$ hydrocarbons, carboxylic acid esters, ketones, terpenes, fatty acids and other components.

\section{Key Words}

Propolis, phenolic components, characterization, balsam..

\section{öz}

$\bigcirc^{n}$ emli bir arı ürünü olan propolis antioksidan, antimikrobiyal, antitumoral, antiinflamatuar özellikleri nedeniyle apiterapi uygulamalarında ve günlük yaşamda gıda takviyesi olarak kullanılmaktadır. Propolisin özellikleri elde edildiği bölgeye, toplanma biçimine ve toplanma zamanına bağlı olarak değiştiğinden her kovandan veya bölgeden aynı özelliklere sahip propolis eldesi mümkün olmamaktadır. Yapılan bu çalışmayla Marmara Bölgesinde yer alan Bilecik ilinden temin edilen ham propolis örneklerinin biyokimyasal özellikleri belirlendi. Meşe, kayın, köknar, ıhlamur, kestane ağaçları ile çevrili olan Bilecik orman bakımından oldukça zengindir. Bu nedenle de zengin bir floraya sahiptir. Bu amaçla; \%70'lik etil alkol çözeltisi kullanılarak ham propolislerden etanolik propolis özütleri hazırlandı. Hazırlanan propolis ekstraktlarının balsam miktarı, vaks miktarı, toplam polifenol miktarı ve toplam flavonoid miktarı belirlendi. GC/MS kullanılarak ham propolislerin içerdiği bileşenler tespit edildi. Propolis için önemli bir değer olan balsam miktarının \%13 ile \%52 arasında değiştiği; toplam polifenol miktarının ise 11 mg GAE/mL ile 76 mg GAE/mL arasında değiştiği belirlendi. Propolis örneklerinin aldehitler, alifatik asit ve esterler, alkoller, hidrokarbonlar, karboksilik asit esterleri, ketonlar, terpenler, yağ asitleri ve diğer bileşenler bakımından zengin olduğu belirlendi.

\section{Anahtar Kelimeler}

Propolis, fenolik bileşenler, karakterizasyon, balsam.

Article History: Received: Jul 18, 2019; Revised: Aug 2, 2019; Accepted: Aug 24, 2019; Available Online: Nov 1, 2019.

DOI: https://doi.org/10.15671/hjbc.593940

Correspondence to: M. Keskin, Vocational School of Health Services, Bilecik Şeyh Edebali University, Bilecik, Turkey.

E-Mail: merveozdemirkeskin@gmail.com 


\section{INTRODUCTION}

D ropolis is a resinous mixture which is collected by bees from leaves, buds and bark parts of plants and is a natural bee product that plays role in protecting hives against all kinds of danger. People have been used propolis in many areas from mummification to treatment of infectious diseases from ancient times to the present [1-3]. Propolis contains various essential oils, aldehydes, aliphatic acid and esters, alcohols, hydrocarbons, carboxylic acid esters, ketones, terpenes, fatty acids and other compounds. Because of these compounds propolis has high antioxidant, antimicrobial, antiinflammatory and antitumoral activities. Today, propolis is mostly used as a supportive for general health and functional food.

The composition and production of raw propolis depends on many factors such as flora, harvesting season, collection style and bee strain $[4,5]$. Propolis has a highly complex chemical composition and varies qualitatively and quantitatively for each sample. Studies have focused on propolis extracts and around 300 different compounds found naturally in these extracts have been identified. Essential oils and polyphenolic substances are the major components of these compounds. Polyphenols with a high biologically active value are a large family and can be classified as phenolic acids, flavonoids, prenylated p-coumaric acid and acetogenene lignans, phenolic compounds, di and tri terpenes, sugars, sugar alcohols, hydrocarbons and mineral elements $[6,7]$.

Bilecik Province is located in the southeast of the Marmara Region. It is located on the cutting points of Marmara, Black Sea, Central Anatolia and Aegean Regions. Bilecik has lots of forests with oak, larch, beech, pine, chestnut trees. Having such a diverse forest makes the region rich source of propolis.

In this study, biochemical properties of propolis samples collected from different regions of Bilecik in 2018 were investigated and the profile of Bilecik propolis was determined.

\section{MATERIALS and METHODS}

\section{Materials}

Propolis samples were supplied from local bee keepers in Bilecik city (Kurtkoy, Camiliyayla, Vezirhan, Poyra, Saraycik and Koyunkoy) Turkey in 2018. Camiliyayla is the highest place and it has the least floral sources. The other places are covered with diverse forest. Methanol, Gallic acid, ethanol were purchased from sigma Aldrich, USA. All other reagents were analytical grade.

\section{Methods}

\section{Preparation of Propolis Extracts}

Extraction of propolis samples with ethanol (70\% v/v) was carried out by simple maceration technique separately. 1:10 (g/v) ratio was used for the extraction. Frozen propolis sample was powdered by grinding and $2 \mathrm{~g}$ of this fine powder was mixed with $30 \mathrm{~mL}$ of $70 \%(\mathrm{v} / \mathrm{v})$ ethanol solution. Extraction was carried out for $48 \mathrm{~h}$ on a magnetic stirrer under constant stirring at $150 \mathrm{rpm}$. Finally, mixtures were separately filtered and filtrates were stored at $+4^{\circ} \mathrm{C}$.

\section{Determination of Balsam \%}

Balsam is usually defined as the alcohol soluble fraction of propolis. In order to determine the ratio of balsam, 2 $\mathrm{mL}$ of propolis extract was evaporated and the amount of resulted solid was quantified until reaching a constant weight. The amount of balsam of the extract was calculated and expressed as a percentage value [8].

Determination of Wax \%

The amount of wax in raw propolis samples were determined as [9] method with minor revisions. Frozen propolis samples were powdered by grinding and 3 grams of samples mixed with $15 \mathrm{~mL}$ of methanol. The mixture was carried out for $2 \mathrm{~h}$ on a magnetic stirrer under constant stirring at $150 \mathrm{rpm}$ and stored $-18^{\circ} \mathrm{C}$ for $24 \mathrm{~h}$. After the storing, the mixture was filtrated and the amount of wax was calculated.

\section{Determination of Total Phenolic Content and Flavonoid Content}

Total phenolic content of ethanol propolis extracts (EPE) was determined by using Folin-Ciocalteu method $[10,11]$ Gallic acid as standard. Results were expressed as $\mathrm{mg} \mathrm{GAE} / \mathrm{mL}$. Total flavonoid content of the samples was determined by using aluminum chloride method [12] quercetin as standard. Results were expressed as $\mathrm{mg} \mathrm{QE} / \mathrm{mL}$.

\section{GC-MS Analysis}

Propolis extracts were passed through $45 \mu \mathrm{m}$ pore filters and $2 \mu \mathrm{l}$ extract injected into the GC-MS. The analysis was performed using Agilent brand 5973N Selective Mass Detector, 6890NNetwork GC System (GCMS). DB 
Table 1. . Obtained data for raw propolis samples.

\begin{tabular}{ccccc}
\hline Origin of Sample & Wax $\%$ & Balsam $\%$ & $\begin{array}{c}\text { Total phenolic } \\
\text { content } \\
\mathrm{mg} \mathrm{GAE} / \mathrm{mL}\end{array}$ & $\begin{array}{c}\text { Total flavonoids } \\
\mathrm{mg} \mathrm{QE} / \mathrm{mL}\end{array}$ \\
\hline Kurtköy & $4.4 \pm 0.08$ & $17.7 \pm 0.8$ & $20.335 \pm 0.02$ & $4.13 \pm 0.01$ \\
\hline Camiliyayla & $2.8 \pm 0.02$ & $13.2 \pm 0.4$ & $11.763 \pm 0.03$ & $3.42 \pm 0.02$ \\
\hline Vezirhan & $5.1 \pm 0.06$ & $52.3 \pm 0.6$ & $75.765 \pm 0.08$ & $16.47 \pm 0.02$ \\
\hline Poyra & $4.3 \pm 0.04$ & $13.9 \pm 0.3$ & $11.478 \pm 0.03$ & $2.66 \pm 0.04$ \\
\hline Saraycı & $1.9 \pm 0.03$ & $37.6 \pm 0.4$ & $46.769 \pm 0.07$ & $9.41 \pm 0.04$ \\
\hline
\end{tabular}

5MS column $(30 \mathrm{~m} \times 25 \mathrm{~mm}$ and $0.25 \mu \mathrm{m}$ film thickness) was used. In the gas chromatography section, the temperature was maintained at $50^{\circ} \mathrm{C}$ for 1 minute then $10^{\circ} \mathrm{C}$./min. It was raised to $150^{\circ} \mathrm{C}$. by the rate of increase and maintained at this temperature for 2 minutes after this period. Finally, the injection temperature was increased to $280^{\circ} \mathrm{C}$, and the time was adjusted to 49.5 minutes [13].

\section{RESULTS and DISCUSSION}

It was determined that wax amounts of raw propolis samples collected from 6 different regions of Bilecik ranged from $1.9 \%$ to $4 \%$. Low wax and high balsam are important criteria for propolis quality $[8,9]$. In a research on ethanolic extracts of raw propolis samples collected from Brazil, China and Uruguay, no wax was found in Uruguay propolis extract, but it was stated that wax amount changed between $2.40 \%$ and $30.60 \%$ for other regions [14]. It was reported that wax amount of Anatolian propolis varies between $1.4 \%$ and $9.8 \%$ [15] It is clear that wax value of Bilecik propolis is quite low. The amount of balsam determined in Bilecik propolis ranged between $13.9 \%$ and $52.3 \%$ (Table 1 ).

High amounts of balsam are reported to express high phenolic compounds and low waxes $[8,16]$. Indeed, Popova et al. (2017) stated that crude propolis contains between $40 \%$ and $60 \%$ balsam. It is reported that the amount of balsam in crude propolis samples collected from Spain varies between $52.5-76.2 \%$ and wax value is between 1.8 and $27.7 \%$ [17]. In different Portuguese propolis samples, it was reported that the amount of wax in raw propolis varies between $4.8 \%$ and $16.0 \%$ [18]. Since it is not possible to fully elucidate the phenolic contents of the plant extracts, the phenolic content is expressed in terms of total phenolic content. Total phenolic components are measured by spectrophotometric method based on color complex formation with
Folin-Ciocalteu reagent. The high amount of phenolic content refers to high antioxidant activity while at the same time high biological activity. It is seen that total phenolic content of ethanolic extracts of Bilecik propolis varies between 11.48- 75.77 mg GAE / mL (Table 1). The amount of the total flavonoid ranged between 2.66 $\mathrm{mg} \mathrm{QE} \mathrm{/} \mathrm{mL} \mathrm{and} 16.47 \mathrm{mg} \mathrm{QE} \mathrm{/} \mathrm{mL.} \mathrm{In} \mathrm{a} \mathrm{study,} \mathrm{it} \mathrm{was} \mathrm{re-}$ ported that total polyphenol content of crude propolis samples obtained from Brazil ranged between $8.8 \%$ and $13.7 \%$ and flavonoid content was minimum $0.35 \%$ and maximum $2.7 \%[19]$.

Total phenolic and flavonoid amounts of propolis samples collected from different regions of Bulgaria were determined in order to determine the chemical components of Bulgarian propolis and to make a simple standardization study. It was reported that total phenolic content ranged from $11.2 \%$ to $41.9 \%$ and total flavonoid amount ranged from $2.9 \%$ to $13.5 \%$ [20]. It was reported that total amount of phenolics in Anatolian propolis ranged between 10.6-178 mg GAE / g and the total amount of phenolics increased with increasing amount of balsam [15]. Aliyazıcıoğlu et. al. (2013) reported that total amount of phenolics ranged between 115 to $210 \mathrm{mg} \mathrm{GAE} / \mathrm{g}$ for different Turkish propolis samples [3]. It was reported that total phenolic content ranged between 1.2 to $15.6 \mathrm{mg} / \mathrm{g}$ for Turkish chestnut propolis [21]. It is clear that total phenolic content for propolis samples obtained from different regions of Turkey varies in wide range.

GC-MS analysis was performed to investigate the chemical composition of the propolis extracts (Table 2). As a result of GC-MS analysis, aldehydes, aliphatic acid and esters, alcohols, hydrocarbons, carboxylic acid esters, ketones, terpenes, fatty acids and other compounds were detected in propolis samples. It is clear that our results are consistent with the literature data [22-24]. 
Silici and Kutluca (2005) determined the chemical composition of some Anatolian propolis samples by using GC-MS. They reported that propolis samples were found to be rich in aliphatic acids, esters, flavonoids and other components [25]. Uzel et. al. (2005) determined the chemical composition of four different propolis samples obtained from Anatolia using GC-MS. Their results showed that propolis samples were rich in aromatic acids, fatty acids, aromatic aldehydes, flavone and flavonones [26]. It is clear that our results are compatible with the literature data.

Table 2. . GC-MS Analysis results of propolis samples.

\begin{tabular}{|c|c|c|c|c|c|c|c|}
\hline Compounds & 1 & 2 & 3 & 4 & 5 & 6 & 7 \\
\hline \multicolumn{8}{|c|}{ Aldehydes } \\
\hline 2.4-Dimethylbenzaldehyde & - & 0.03 & - & - & - & 0.06 & 0.02 \\
\hline 2-Methyl-2-pentenal & 0.04 & - & - & - & - & - & - \\
\hline Benzaldehyde & - & 0.03 & - & - & - & 0.41 & \\
\hline Cinnamaldehyde & - & - & - & 0.03 & - & - & - \\
\hline Lauric aldehyde & - & - & 0.30 & 1.30 & - & - & - \\
\hline Phenylacetaldehyde & - & - & - & 1.02 & - & - & - \\
\hline trans. trans-2.4-Hexadienal & - & 0.04 & - & - & - & - & - \\
\hline Total & 0.04 & 1.00 & 0.30 & 2.35 & - & 0.47 & 0.02 \\
\hline \multicolumn{8}{|c|}{ Aliphatic Acid and Esters } \\
\hline Decanoic acid & - & 0.05 & - & - & - & - & - \\
\hline Total & - & 0.05 & - & - & - & - & - \\
\hline \multicolumn{8}{|c|}{ Alcohols } \\
\hline 1-Decanol & - & - & - & 0.30 & - & - & - \\
\hline 3-Octanol & - & - & - & - & 0.17 & - & 0.16 \\
\hline 3-Phenyl-1-propanol & - & - & - & 0.46 & 0.15 & - & - \\
\hline alpha-Methylbenzylalcohol & - & - & - & - & 0.51 & - & - \\
\hline Benzyl alcohol & 14.46 & 0.08 & 1.31 & 1.23 & 1.10 & 0.32 & 11.36 \\
\hline Farnesol & 0.45 & 3.28 & 0.33 & - & 6.65 & 0.47 & - \\
\hline Furfuryl alcohol & 0.04 & - & - & - & - & - & - \\
\hline Geraniol & - & - & - & - & 1.64 & - & - \\
\hline Lauryl alcohol & 0.92 & - & - & 0.52 & - & - & - \\
\hline Phenethyl alcohol & 4.41 & 0.16 & 1.63 & 2.14 & 1.16 & 0.90 & 2.26 \\
\hline Total & 20.28 & 3.52 & 3.27 & 4.65 & 11.38 & 1.69 & 13.78 \\
\hline \multicolumn{8}{|c|}{ Hydrocarbons } \\
\hline n-Tetracosane & - & 2.20 & - & - & - & 0.59 & - \\
\hline Total & - & 2.20 & - & - & - & 0.59 & - \\
\hline \multicolumn{8}{|c|}{ Carboxylic Acids and Esters } \\
\hline Benzoic acid & 1.32 & - & 0.93 & - & 1.08 & - & 0.05 \\
\hline Total & 1.32 & - & 0.93 & - & 1.08 & - & 0.05 \\
\hline \multicolumn{8}{|c|}{ Ketones } \\
\hline 2-Nonanone & - & - & 0.38 & - & - & - & - \\
\hline 2-undecanone & - & - & - & 0.56 & - & - & - \\
\hline 4'-Methylacetophenone & - & - & - & - & 0.19 & 0.53 & - \\
\hline 6-Methyl-3.5-heptadien-2-one & - & 0.12 & - & - & - & - & - \\
\hline Menthone & 4.91 & - & 1.96 & - & 2.76 & - & 0.71 \\
\hline omega-Pentadecalactone & - & - & - & - & - & 0.74 & - \\
\hline Total & 4.91 & 0.12 & 2.34 & 0.56 & 2.95 & 1.27 & 0.71 \\
\hline
\end{tabular}


Table 2. GC-MS Analysis results of propolis samples. Continued.

\begin{tabular}{|c|c|c|c|c|c|c|c|}
\hline Compounds & 1 & 2 & 3 & 4 & 5 & 6 & 7 \\
\hline \multicolumn{8}{|c|}{ Terpenes } \\
\hline Isoborneol (isomer 1) & - & 0.04 & - & - & - & - & - \\
\hline Limonene & - & - & - & - & - & 0.84 & - \\
\hline Total & - & 0.04 & - & - & - & 0.84 & - \\
\hline \multicolumn{8}{|c|}{ Fatty Acids } \\
\hline Decyl acetate & - & - & - & - & 0.58 & - & - \\
\hline Lauric acid & - & - & - & - & 0.73 & -- & - \\
\hline Myristic acid & - & - & 0.34 & - & 0.14 & - & - \\
\hline Palmitic acid & 0.53 & 0.76 & - & 0.45 & - & 0.48 & - \\
\hline Stearic acid & - & 0.03 & 0.37 & 0.28 & - & - & - \\
\hline Total & 0.53 & 0.79 & 0.76 & 0.73 & 1.45 & 0.48 & - \\
\hline \multicolumn{8}{|c|}{ Other Compounds } \\
\hline 2.3.5.6-Tetramethylpyrazine & - & - & - & 0.12 & - & - & 2.83 \\
\hline 3-Phenylpropionic acid & 0.10 & 0.18 & 0.24 & - & 0.14 & 0.13 & - \\
\hline Acetanisole & 0.03 & - & - & - & 0.71 & - & 3.97 \\
\hline alpha-Pinene & - & - & 0.02 & - & - & - & - \\
\hline Benzyl acetate & 0.17 & - & - & - & - & - & - \\
\hline Benzyl benzoate & 0.12 & - & - & - & 0.13 & - & 0.12 \\
\hline Benzyl cinnamate & 0.31 & - & - & - & 0.57 & - & - \\
\hline beta-Caryophyllene & - & - & - & - & - & - & 0.39 \\
\hline beta-Damascone & - & - & 0.63 & - & - & - & - \\
\hline beta-Ionone & - & 1.08 & 0.73 & - & 0.60 & - & - \\
\hline Carvacrol & 3.06 & 0.30 & 0.48 & - & - & - & - \\
\hline Cinnamil acetate & 0.06 & - & - & - & - & - & - \\
\hline Citronellal & - & 1.80 & - & - & 0.25 & - & 0.24 \\
\hline Delta-3-carene & - & 0.06 & - & - & - & - & - \\
\hline Ethyl cinnamate & 0.06 & 0.11 & 0.07 & - & 0.07 & 0.10 & 0.04 \\
\hline Ethyl laurate & - & 0.08 & - & - & - & - & - \\
\hline Ethyl oleate & - & 3.34 & - & - & - & 0.39 & - \\
\hline Ethyl palmitate & - & 1.10 & - & - & - & - & - \\
\hline Ethyl-3-hydroxyhexenoate & - & 0.10 & - & - & - & - & - \\
\hline Ethylphenyl acetate & - & - & - & - & - & 0.88 & - \\
\hline Eucalyptol & - & - & 0.11 & - & - & - & - \\
\hline Eugenol & 0.46 & - & 0.22 & - & - & - & - \\
\hline Geranylaceton (Isomer 1) & - & - & - & - & - & 0.57 & - \\
\hline Guaiacol & 1.05 & - & - & - & - & - & - \\
\hline Indole & 1.00 & 0.78 & 0.17 & 1.03 & 0.32 & 1.52 & - \\
\hline Linaloxide (cis. isomer B) & - & - & - & 1.51 & 0.84 & 1.35 & - \\
\hline Linaloxide (trans. isomer A) & - & - & - & - & 0.09 & - & 0.75 \\
\hline Linaloxide (trans. isomer B) & - & - & 0.64 & - & - & - & - \\
\hline Linalyl formate & - & - & - & 0.88 & - & - & - \\
\hline Methyl benzoate & - & - & - & - & - & - & 0.05 \\
\hline Methyl octine carbonate & - & - & - & - & 0.14 & - & - \\
\hline Methyl phenyl acetate & - & - & - & 0.30 & - & - & 0.32 \\
\hline
\end{tabular}


Table 2. GC-MS Analysis results of propolis samples. Continued. Continued.

\begin{tabular}{cccccccc}
\hline Compounds & 1 & 2 & 3 & 4 & 5 & 6 & 7 \\
\hline Methyl phenylethyl ether & 0.25 & - & - & - & - & - & 0.07 \\
\hline Methyl-gamma-lonone (isomer 1) & 0.41 & - & - & 0.23 & 0.23 & - & - \\
\hline Methylvalerate & - & - & 0.07 & - & - & - & - \\
\hline Neryl acetate & - & - & 0.04 & - & - & - & - \\
\hline Nonyl acetate & 0.22 & - & - & - & - & - & - \\
\hline p-Cresol & - & 0.20 & - & - & - & - & - \\
\hline Phenethyl butyrate & - & - & 0.02 & - & - & - & - \\
\hline Phenethylamine & - & - & 0.02 & - & - & - & - \\
\hline Quinoline & 0.76 & 0.24 & 0.44 & 0.75 & 0.41 & 0.75 & - \\
\hline Styrene & 0.61 & - & - & 0.14 & - & 0.08 & 0.13 \\
\hline Valencene & - & - & 0.18 & - & - & - & 0.42 \\
\hline Vanillin & 0.30 & - & 0.57 & 1.26 & 0.20 & 1.39 & 0.80 \\
\hline Total & 0.19 & - & - & - & 0.32 & - & 0.12 \\
\hline
\end{tabular}

\section{Conclusion}

In this study, physical and biochemical properties of propolis of Bilecik province were determined. It is clear that the amount of wax and balsam for Camiliyayla sample was found to be lower than the other samples. This shows that the amount of balsam is related to the flora of the region. Propolis samples with lower wax and higher balsam content seems to have more biologically active components.

\section{References}

1. M.R., Ahn, S., Kumazawa, Y., Usui, J., Nakamura, M.,Matsuka, F. Zhu, T. Nakayama, Antioxidant Activity and Constituents of Propolis Collected in Various Areas of China, Food Chem. 101 (2007) 1383-1392.

2. R., Aliyazıcioglu, H., Sahin, O., Erturk, E., Ulusoy, S., Kolayli, Properties of phenolic composition and biological activity of propolis from Turkey, Int. J. Food Prop., 16 (2013) 277-287.

3. F., Li, S., Awale, Y., Tezuka, S., Kadota, Cytotoxic Constituents From Brazilian Red Propolis and Their Structure-Activity Relationship, Bioorg., Med., Chem., 16 (2008) 5434-5440

4. R.O., Silva, V.M., Andrade, E.S., Bulle Rego, G.A., Azevedo Doria, B.,Santos Lima, F.A., Silva, A.A.S., Araújo, Acute and sub-acute oral toxicity of Brazilian red propolis in rats. J. Ethnopharm., 170 (2015) 66-71.

5. M.S.R., Neto, S.R., Tintino, A.R.P., da Silva, M.S., Costa, A.A. Boligon, E.F.F., Matias, V.Q., Balbino, R.A., Irwin Menezes, H.D.M. Coutinho, Seasonal variation of Brazilian red propolis: Antibacterial activity, synergistic effect and phytochemical screening. Food Chem. Toxic., 107 (2017) 572-580.

6. Ö., Saral, Determination of Antioxidant Activities of the Chestnut and Flower Honeys Collected from Eastern Black Sea Region in Turkey. J. Apit. Nat., 1 (2018) 28-32.
7. E., Talla, A., Tamfu, P., Biyanzi, P., Sakava, F., Asobo, J., Mbafor, N. F., Tchuenguem, R., Ndjouenkeu,. Phytochemical Screening, Antioxidant Activity, Total Polyphenols and Flavonoids Content of Different Extracts of Propolis From Tekel (Ngaoundal, Adamawa Region, Cameroon), J. Phytopharmac., 3 (2014) 321-329.

8. M., Popova, E., Giannopoulou, K., Skalicka-Wo'zniak, K., Graikou, J., Widelski, V., Bankova, H., Kalofonos, G., Sivolapenko, K., Gaweł- B eben, B., Antosiewicz, I., Chinou, Characterization and Biological Evaluation of Propolis from Poland, Molecules, 22 (2017) 1159.

9. X., Feás, L., Pacheco, A., Iglesias, L.M., Estevinho, Use of Propolis in the Sanitization of Lettuce,, Int. J. Mol. Sci.,15 (2014) 12243-12257.

10. V. L. Singleton, J.A., Rossi Colorimetry of Total Phenolics with Phosphomolybdic-Phosphotungstic Acid Reagents, American J. Eno. Vitic., 16 (1965) 144-158.

11. V. L., Singleton, R.Orthofer, R.M., Lamuela-Raventos, Analysis of Total Phenols and Other Oxidation Substrates and Antioxidants by Means of Folin-Ciocalteu Reagent, Methods in Enzy., 299 (1999) 152-178.

12. L. R., Fukumoto, G., Mazza, Assessing antioxidant and prooxidant activities of phenolic compounds, J. Agric. Food Chem., 48 (2000) 3597-3604

13. B., Trusheva, M., Popova, E. B., Koendhori, I., Tsvetkova, C., Naydenski, V., Bankova, Indonesian propolis: Chemical composition, biological activity and botanical origin, Nat. Prod. Res., 25 (2011) 606-613.

14. J.S., Bonvehi, F.V., Coll, R.E., Jorda, The Composition Active Components and Bacteriostatic Activity of Propolis in Dietetics, JAOCS, 71 (1994) 18-25.

15. M., Keskin, S., Kolaylı, Standardization of Propolis, is it Possible?, Uludağ Arıcılık Dergisi - Uludag Bee Journal, 18 (2018) 101-110.

16. V., Bankova, S., De Castro, M., Marcucci, Propolis: recent advances in chemistry and plant origin, Apidologie, 31 (2000) 3-15. 
17. J. S. Bonvehi, A. L.. Gutierrez, Antioxidant Activity and Total Phenolics of Propolis from the Basque Country (Northeastern Spain), Am. Oil Chem. Soc., 88 (2011) 1387 1395.

18. L.G., Dias, A.P., Pereira, L.M., Estevinho, Comparative Study of Different Portuguese Samples of Propolis: Pollinic, Sensorial, Physicochemical, Microbiological Characterization and Antibacterial Activity, Food Chem. Toxic., 50 (2012) 42464253.

19. R. G., Woisky, A., Salatino,. Analysis of propolis: some parameters and procedures for chemical quality control, J. Apic. Res., 37 (1998) 99-105.

20. V., Bankova, A., Dyulgerov, S., Popov, N., Marekov, A GC/MS Study of the Propolis Phenolic Constituents, Z. Naturforsch, 42 (1987) 147-151.

21. A.O., Sarıkaya, E., Ulusoy., N., Öztürk, M., Tunçel, S., Kolaylı, Antioxidant Activity And Phenolic Acidconstituents of Chestnut (Castania Sativamill.) Honey And Propolis, J. Food Biochem., 33 (2009) 470-481.
22. N., Duran, M., Muz, G., Culha, G., Duran, B., Ozer, GCMS analysis and antileishmanial activities of two Turkish propolis types, Parasitol. Res., 108 (2011) 95-105.

23. M. Popova, S. Silici, O. Kaftanoglu, V. Bankova, Antibacterial activity of Turkish propolis and its qualitative and quantitative chemical composition, Phytomedicine, 12 (2005) 221-228.

24. H., Katircioglu, N., Mercan, Antimicrobial activity and chemical compositions of Turkish propolis from different regions, African J. Biotech., 5 (2006) 1151-1153.

25. S., Silici, S., Kutluca, Chemical composition and antibacterial activity of propoliscollected by three different races of honeybees in the same region, J. Ethnopharmacology, 99 (2005) 69-73.

26. A., Uzel, K., Sorkun, O., Onçă̆, D., Çoğulu, O, Gencay, B., Salih, Chemical compositions and antimicrobial activitiesof four different Anatolian propolis samples, Mic. Res., 160 (2005) 189-195. 